\title{
ФОРМИРОВАНИЕ ИНСТИТУЦИОНАЛЬНЫХ УСЛОВИЙ РАЗВИТИЯ СИБИРИ И ДАЛЬНЕГО ВОСТОКА: ГРАДОСТРОИТЕЛЬНЫЙ АСПЕКТ
}

\author{
(C) 2021 Наумов Александр Сергеевич \\ кандидат экономических наук, старший научный сотрудник \\ Институт экономики РАН, Россия, Москва \\ E-mail: as.naumov@mail.ru
}

Проанализированы исторические, зарубежные и современные российские взгляды и стратегии на структурные изменения в экономическом развитии Сибири и Дальнего Востока с точки зрения формирования их институциональных условий и с учетом зарубежного опыта. Указаны негативные тенденции, замедляющие этот процесс. Даны рекомендации и предложения, способствующие их устранению.

Ключевые слова: стратегия развития, городские агломерации, миграция населения, административный ресурс, социально-экономическое развитие, институциональные особенности, инфраструктура, мобильность населения, ментальность.

Проблема развития северных территорий довлела над власть имущими на всем протяжении российской истории. В начале 20-ого века российский исследователь Н.А. Рожков писал в своем труде «Город и деревня в русской истории (краткий очерк экономической истории России)» буквально следующее: «Вопрос о взаимных отношениях и значении города и деревни в человеческом общежитии принадлежит к числу самых жгучих, наиболее волнующих общество... он приобретает особенную жгучесть в настоящее время в нашем отечестве в силу тех экономических перемен, какие приходится переживать России». [1 - С. 1]

Речь идет в первую очередь о росте народонаселения после отмены крепостного права, японской угрозе на Дальнем Востоке и назревающих переменах во властных структурах т.е. ограничении самодержавия, неизбежность земельной реформы и развития экономики за счет сибирских территорий. Вопрос можно было решить только строительством городов: административных, военных, горнодобывающих, торгово-экономических и социокультурных образований. Другой исследователь, Вениамин Семенов-Тян-Шанский в Записках императорского русского географического общества писал: «Сгущение городского населения на Запад и на Восток - на сухопутных гранях с Западной Европой и Сибирью - явление не случайное, обусловленное только чисто местными причинами... его причины лежат глубже и заключаются в том, что как раз здесь находятся точки соприкосновения Среднего мира, в пределах главной колонизационной оси, с более чем он культурными (европейскими) территориями на Западе с менее культурными чем он (сибирскими) территориями на Востоке». [2 - С. 208]

В этом схождении он видел историческую миссию России. Оба исследователя четко понимали необходимость таких преобразований, усматривая в них защиту от территориального развала. «Но территориальная протяженность, при малейших застоях культуры в центре колонизационной волны, есть злейший внутренний враг ее политической целостности и соблазн для более культурных соседей, об этом нельзя забывать ни на минуту», - писал Вениамин Семенов-Тян-Шанский. [2 - С. 210]

Здесь необходимо отметить, что, в той или иной мере, затронутые проблемы и опасения исследователей актуальны в новейшее время нашей истории.

Решение этой исторической задачи без веры в нее населения страны представляется нам трудно выполнимой. Некоторые объяснения на этот счет содержатся в книге Г. Гачева «Ментальности народов мира». Большую, если не основополагающую, роль в исторических событиях (по его мнению) играет ментальность, так Г. Гачев пишет по этому поводу - «...национальное в народе есть как бы почва его исторического развития, ему предшествует». [3 - С. 29] Так, искусственно созданная американская цивилизация не имеет в своем активе «тягот прежних угрызений и гнилых традиций», в то же время у русской цивилизации есть неодолимая тяга «к родному пепелищу и отеческим гробам» и т.д. Можно спросить, а как это со- 
относится с экономическими категориями и инновационными устремлениями? Здесь Г. Гачев утверждает: «Душа американца одержима работой... в протестанткой этике Богом благословлен именно homo faber, человек работающий. Упорный труд, изобретательность, терпеливость позволяют американцам довести свою задачу до логического завершения, когда можно поставить точку. [3 - С. 196] В русской же мысли в общем оставляет вопрос не решенным, многоточие ставится в конце, а не точка». [3 - С. 198]

Решение этой проблемы в России на всем ее историческом протяжении - виделось в создании сильного государства с лидером во главе, которое принуждает, как к освоению (с разной степенью успешности) обширных территорий, так и к модернизации старых. Здесь нельзя не сказать о том, что степень принуждения напрямую зависит от итогов колонизационных процессов. Вот как это объясняет Г. Гачев: «Ну а главная разница - в темпо ритмах Времени, Космос России - Север суровый присоединен к линии умеренных широт. Космос США - к линии умеренных широт присоединен юг... В США все темпы естественно скоры, да еще и искусственно ускорены... У нас же естественно замедленны все процессы, а ускоряются-подстегиваются волей Державы, организатора трудов. На частной инициативе тут далеко не уедешь: ну как приватизировать тундру». [3 - С. 213].

На эти обстоятельства многократно указывали российские исследователи, так Л. Никифоров отмечал что «национальный менталитет есть синтетический результат воздействия на национальные или этнические черты постоянных естественных факторов и внутренней и внешней общественной среды, которая сама в значительной мере складывается под воздействием этих факторов». [4 С. 47-48] Заявленный разворот на Восток должен содержать в себе прежде всего комплексное развитие внутреннего рынка, поиск механизмов формирования агломераций, развитую инфраструктуру, поиск и создание новых институтов, позволяющих осуществить задуманное и, тем самым, существенным образом повлиять на менталитет народов нашей страны. Данное обстоятельство можно подытожить примерами из жизни Советской России, так все значимые преобразования Сибири и Дальнего Востока происходили на фоне грандиозного социо-культурного (кино, литература) и информационного влияния (газеты, журналы, радио). Сегодня эти возможности гораздо шире, но не используются должным образом. Между тем, многие исследователи указывают на то, что ментальность можно и нужно рассматривать как категорию экономическую.

«Ментальность как экономическая категория» так назвали свое исследование ученые ИЭ РАН Л. Евстигнеева и Р. Евстигнеев. В нем они объясняют, что «В современном мире ментальность активно вписывается в экономику и общество. Становясь эндогенным фактором развития, она все более определяет социальный тонус экономического роста и стабильность в обществе. Осмысление этих процессов требует изучения ментальности как экономической категории, приводящей к единству способа производства и способ жизни.» [5 - С. 84]

В довершение к вышеизложенному добавим то, что западные исследователи Сибири Хилл Ф. и Пэдди К. В книге «Сибирское бремя», как бы повторяя тезис Г. Гачева, определяют проблему следующим образом: «В России взаимосвязь и единство привносятся сверху. Вертикаль власти нужно устанавливать и укреплять тогда, когда не существует горизонтальных связей. Однако, если бы размещение городов было экономически оправданным - если бы размещение людей определялось экономическими движущими силами, - тогда могли бы образоваться естественным путем и рациональные политические связи и административные структуры. Экономические связи являются основой для образования реальных политических связей. Они, в свою очередь, делают возможным местное самоуправление». [6 - С. 46] В основном эти положения не противоречат тем тенденциям в экономике и общественной жизни, которые происходят сейчас.

Реалии же таковы, что нам предлагается грандиозный проект по созданию в Сибири и на Дальнем Востоке сети агломераций с городами-миллионниками во главе. Новое освоение этих территорий жизненно необходимо, там, в непосредственной близости, находятся новые центры мирового развития, которые готовы ко взаимному сотрудничеству на долгосрочной основе.

Ученые РАН периодически предлагают обществу различные стратегии развития региона, так в «Аналитическом докладе. Сценарии развития Восточной Сибири и российского Дальнего Востока» под научным руководством Академик-секретаря ООН А. Кокошина были представлены сценарии развития Восточной Сибири и Даль- 
него Востока до 2030 года. Привлекает внимание третий сценарий - «Новые возможности», на наш взгляд наиболее оптимистичный. В нем говорится о том, что «развитие минерально-сырьевой базы регионов происходит на системной основе с выделением крупных центров экономического роста. По оценкам, реализация сценария «Новые возможности» позволит увеличить совокупный ВРП регионов Восточной Сибири и Дальнего Востока в 5-6 раз к 2030 г. по сравнению с 2010 г. Среднедушевой ВРП в Восточной Сибири и на Дальнем Востоке в этом случае составит в 2030 г. 48 тыс. долл., а численность населения увеличится до 16,8 млн. чел.» [7- С. 8].

Подобные намерения не выглядят утопично, достижения зарубежных стран, имеющих сходные географические и климатические условия указывают на то, что при взвешенном и рациональном подходе можно добиться хороших результатов и на российских сибирских просторах. Подробнее об этом можно прочитать в исследовании Хилл Ф. Гэдди К. Сибирское бремя. Журнал «Международные процессы» М. - 2007. Ценность доклада А. Кокошина заключается на наш взгляд в том, что тянуть с развитием восточных территорий больше нельзя. Тем более, что государственные деятели, финансисты и ученые, прямо или косвенно, участвовавшие в этом исследовании, его поддерживают. В связи с этим можно сказать, что обеспечение экономической и социальной мобильности в деле развития северных территорий, а не просто изменение системы - может стать вызовом России в последующие годы.

Одним из элементов этого Вызова, как писал исследователь Л. Никифоров, находится «в структуре пространства, образуемого под воздействием общественной среды, выделяется экономическое и социальное пространство. Экономическое пространство зависит от характера экономических отношений, содержание которых влияет на освоенность территории, характер хозяйственных связей, организация экономического оборота, развитость внутреннего и внешнего рынков и т.п.» [4 - С. 25]

Сводить все развитие территорий к материально ресурсной, преимущественно сырьевой, отраслевой специализации на основе градостроительства и создания агломерации без учета комплексно-мобилизационного создания социальной среды представляется недостаточным, ибо это оказывает негативное влияние на исход населения с заявленных территорий. Перспектива не радужная. Для изменения ситуации необходи- мо прежде всего развивать инфраструктуру, создавать привлекательные долгосрочные рабочие места для квалифицированных кадров, строить города по новым более современным технологиям и модернизировать старые. Для этого необходимо отработать модель, куда включить изменения как в институциональном развитии, так и инновационном поле в целях трансформации процессов в заданном направлении.

В процессе разработки Стратегии развития городов и строительства новых можно обратиться к опыту, накопленному в субъектах Российской Федерации. Так в документе «Стратегия развития города Москвы на период до 2025 года», разработанном учеными Москвы под руководством ИЭ РАН были даны современные методы, показаны перспективы научных подходов в деле градостроительства, предложены инструменты для решения насущных проблем (экономических, финансовых, социо-культурных, транспортных и др.).

Интересный документ был внесен на суд научной общественности на конференции «Сибирского клуба» в Красноярске. «В нем представлен краткий анализ социально-экономических проблем Сибири и Дальнего Востока, сформулированы предложения к долгосрочной стратегии развития макрорегиона Сибирь. Показано, что перспектива развития России в XXI веке тесно связана с восстановлением ее исторического «движения» на Восток. Сформулированы предложения к ряду ключевых политик, обеспечивающих ускоренное развитие макрорегиона Сибирь, включая промышленную политику, политику стимулирования инвестиций, политику эффективного недропользования, политику пространственного развития и развития инфраструктуры, политику наращивания человеческого капитала, политику бюджетного федерализма.» [8 - С. 1] Тем самым показано, что руководители государства, политики, ученые и просто здравомыслящие граждане России соединились в понимании скорейшего развития Сибири и Дальнего Востока.

В заключение хочется привести слова истинного патриота Семенова-Тян-Шанского:«Когда же наша волна окончательно закрепится на своем восточном конце... наконец получит должную их численности и самобытностной даровитости от всего мира и сможет выдержать какие угодно бури ... и какое угодно соперничество», - писал в начале 19 века русский исследователь [2-С. 211]. 


\section{Библиографический список}

1. Рожков Н.А. Город и деревня в русской истории (Краткий очерк экономической истории России). С. - Петербург. Типография И.Н. Скороходова. 1902.

2. Семенов-Тянь-Шанский В. Город и деревня в европейской России (очерк по экономической географии). С.-Петербург. Типография В.А. Киршбаума. 1910.

3. ачев Г. Ментальности народов мира./Эксмо Алгоритм. М., 2008.

4. Никифоров Л. Трактовка пространственного потенциала и его роль в стратегии социально-экономического развития России. //ИЭ РАН. М,. 2011.

5. Евстигнеева Л., Евстигнеев Р. Ментальность как экономическая категория.// Общественные науки и современность. М., 2011. № 4 - С. 84-95.

6. Хилл Ф., Гэдди К. Сибирское бремя. Журнал «Международные процессы».М. - 2007. - С. 328

7. Аналитический доклад. Сценарии развития Восточной Сибири и российского Дальнего Востока. Научный рук. Академик-секретарь Оон РАН Кокошин А. //изд. Едиториал УРСС. М., 2011.

8. Россия: восточный вектор. Предложения к стратегии развития Сибири и Дальнего Востока. Аналитический доклад/под ред. В.С. Ефимова, В.А. Крюкова. - Красноярск: Сиб. федерал. ун-т, 2014. - 92 с. https://zen. me/1WUqmH 